\title{
HEARING SCREENING OF SCHOOL CHILDREN IN THE PODKARPACKIE VOIVODESHIP, POLAND
}

\author{
Piotr Henryk Skarzynski ${ }^{1,2,3}$, Weronika Swierniak ${ }^{1}$, Dorota Szuber ${ }^{3,4}$, Natalia Czajka ${ }^{1}$, \\ Henryk Skarzynski ${ }^{5}$ \\ ${ }^{1}$ Department of Teleaudiology and Screening, World Hearing Center, \\ Institute of Physiology and Pathology of Hearing \\ ${ }^{2}$ Department of Heart Failure and Cardiac Rehabilitation, Faculty of Medicine, \\ Medical University of Warsaw \\ ${ }^{3}$ Institute of Sensory Organs \\ ${ }^{4}$ Podkarpackie Center of Hearing and Speech MEDINCUS \\ ${ }^{5}$ Department of Oto-Rhino-Laryngosurgery, World Hearing Center, \\ Institute of Physiology and Pathology of Hearing
}

\begin{abstract}
INTRODUCTION: Hearing screening is an important part of prevention. It allows early detection of hearing disorders, thus the treatment may begin early, and eliminates or minimises negative consequences. Children with hearing impairment often experience delayed speech development and cognitive abilities, which can result in learning disabilities and reduce school progress. Since 1999, the Institute of Physiology and Pathology of Hearing in Poland has provided a hearing screening program for school-age children in the country. The main aim of the program is the early detection of hearing disorders in children starting school, and increase in the awareness among parents of hearing problems.

MATERIALS AND METHODS: Pure-tone air-conduction hearing thresholds were obtained at 0.5-8 kHz. The results of the hearing screening examination were regarded as positive if pure-tone thresholds were higher than $20 \mathrm{~dB}$ HL in one or both ears at one or more of the test frequencies. The audiometric results were supplemented by questionnaires completed by the parents. There were 8,091 first-grade children from the Podkarpackie Voivodeship enrolled in the program.

RESULTS: Based on the audiogram, screening showed that hearing impairment was found in 1618 children ( $20 \%$ of the examined children).

CONCLUSION: Our study yielded a large group of children with hearing problems. We recommend that hearing screening in primary schools should be a routine procedure within a general framework of preventive pediatric health care.
\end{abstract}

Keywords: hearing screening, hearing loss, school screening, pure tone audiometry

Address for correspondence:

Piotr Henryk Skarzynski

World Hearing Center

Institute of Physiology and Pathology of Hearing

17 Mokra St

05-830 Kajetany, Nadarzyn

Poland

e-mail:p.skarzynski@csim.pl

Received: May 16, 2021

Accepted: June 15, 2021

\section{INTRODUCTION}

Hearing loss (HL) is the most common sensory impairment. The prevalence of HL among children is estimated to be between $7.7 \%$ and $22.5 \%$, depending on the criteria applied (1-3). Hearing screening in schools is used to identify conditions that prevent students from reaching optimal physical and mental levels. Good hearing is fundamental to language development, which is essential for learning when 
a child starts school. The early detection of hearing disorders means a child can receive appropriate treatment and education, improving the child's overall well-being. The goal of school hearing screening programs is to identify students with potential hearing deficits at the earliest possible stage so that they can be referred for diagnosis and treatment, if required. However, it needs to be kept in mind that a hearing screening test does not provide a firm diagnosis of HL, only an indication that the child is at risk of having a hearing disorder and requires further assessment by an audiologist or ENT specialist.

According to the European Scientific Consensus agreement, drawn up and signed during the $\mathrm{Eu}-$ ropean Federation of Audiology Societies meeting in Warsaw, June 2011, untreated hearing loss of $>20$ $\mathrm{dB}$ can have a negative impact on speech, language, and cognitive development, and subsequently on academic achievements (4). In the light of predicted trends in hearing loss, the World Health Organization underlines the importance of preventative actions; it emphasizes the value of hearing care at the community level as well as of screening and intervention services to high-risk populations, including schoolchildren (5). Even school children with only mild hearing loss, who appear to function normally in everyday situations, are nonetheless at risk of academic, social, and behavioural problems., Identification of even mild hearing loss is therefore important, because it allows effective treatment to be undertaken before significant damage is done (6). School hearing screening programs are an opportunity to reduce the health and economic burden of childhood hearing loss. However, even in regions which have routine neonatal screening programs, childhood hearing loss is still a generally neglected public health problem $(7,8)$.

The Institute of Physiology and Pathology of Hearing, in collaboration with the Polish Agricultural Social Insurance Fund, has performed a screening program for school children from rural areas and small towns in eastern Poland (9), a programme that has subsequently been extended to the western part of the country (10). This paper presents the results of a study in the Podkarpackie Voivodeship of Poland on the number on first-grade children who have HL.

\section{MATERIALS AND METHODS}

The number of children included in the program amounted to 8,091 children (4,020 girls; 4,071 boys). Hearing screening tests were carried out among these first grade children at the age of 7 years in 543 general primary schools in rural areas. All schools were located in 21 communes in the Podkarpackie Voivodeship. A considerable difficulty in carrying out the program was the wide dispersal of schools in the regions involved. In the rural regions and small towns (below 5,000 inhabitants) the majority were small schools in which the number of involved children was often less than 20 .

The study was approved by the Ethics Committee of the Institute of Physiology and Pathology of Hearing (KB.IFPS:27/5/2018) and conformed to the Declaration of Helsinki. Prior to testing, the child's parents or legal caregivers were informed of the testing procedures and gave written consent before the child entered the study. Information about the programme, together with a booklet about hearing prophylaxis and the examination consent forms, were delivered to schools through local administration units (communes). Teachers distributed the materials to parents at face-to-face meetings.

In this study, the screening examinations were part of an educational campaign directed to parents and their children. The main goal was to broaden knowledge of the potential causes of HL and the options for prophylaxis, diagnosis, treatment, and rehabilitation of hearing disorders. The educational materials were mainly aimed at parents, who are undoubtedly the first and most important "health teacher" for the child (11). In addition, a hearing guide for children was prepared in which the most important principles of caring for hearing were simply set out.

Screening pure-tone audiometry was performed using the Platform of Sensory Organs Examinations $(12,13)$. The platform is built on an internet network, interfacing a central computer system with a series of portable computers (remote clients) that are equipped with audiometric headphones and a response button. The platform makes it possible to perform air conduction audiometric testing on each ear separately over a frequency range 0.5 to $8 \mathrm{kHz}$ and for levels not exceeding $80 \mathrm{~dB}$ HL. Tests were carried 
Piotr Henryk Skarzynski, Weronika Swierniak, Dorota Szuber et al.

out in quiet rooms in accordance with the modified Hughson and Westlake procedure $(14,15)$. A positive test result was considered to be an air conduction threshold of $25 \mathrm{~dB}$ HL or more at a minimum of one frequency in at least one ear $(12,16,17)$. Audiometric hearing tests were supplemented by the results of a questionnaire filled in by parents or legal caregivers. The questionnaire included the following questions: Do you think your child has any problems with his/her hearing? Does your child complain of tinnitus in their ears/head when it is quiet? Has your child been treated for otitis media? Does your child complain about noise at school?

The data of the hearing tests were sent via an internet connection to the SZOK system and safely stored in a database $(13,17)$. The collected results were marked with a unique identifier which guarantees full protection of personal data in accordance with applicable law. This is a unique solution in the field of telemedicine and e-health. After the results of the tests were transferred to SZOK, incorrect test results (according to fixed criteria) were separated out by an audiologist and an ENT specialist.

The positive results of the screening test were $\diamond$ Low-frequency hearing loss (LFHL): for cases presenting a hearing threshold at 500 and/or $1000 \mathrm{~Hz}$ above $20 \mathrm{~dB} \mathrm{HL}$, while the threshold for the other tested frequencies was normal.

$\diamond$ High-frequency hearing loss (HFHL): for cases presenting a hearing threshold at 4000 and/ or $8000 \mathrm{~Hz}$ above $20 \mathrm{~dB} \mathrm{HL}$, while the hearing threshold for other tested frequencies was normal.

$\diamond$ Other: cases where the hearing threshold was above $20 \mathrm{~dB} \mathrm{HL}$ at two or more arbitrary frequencies.

\section{RESULTS}

Positive results from the hearing screening, according to the adopted criterion, were obtained in 1618 children (20\% of examined children). Unilateral hearing loss was found in the majority of children with a positive result of the hearing screening $(68.3 \%)$ compared to a smaller number with bilateral hearing loss (31.7\%). The distribution of left and right ears was similar. The percentage of positive results was slightly higher among boys than among girls. Detailed results are shown in Table 1.

Table 1. Percentage of students with hearing loss and the frequency of unilateral and bilateral hearing loss divided by sex

\begin{tabular}{|c|c|c|c|c|c|}
\hline \multirow[t]{2}{*}{ Sex } & \multirow{2}{*}{$\begin{array}{l}\text { Number of } \\
\text { Children } \\
\text { Screened }\end{array}$} & \multirow{2}{*}{$\begin{array}{l}\text { Number of } \\
\text { Children with } \\
\text { Positive Result }\end{array}$} & \multirow[t]{2}{*}{ Bilateral } & \multicolumn{2}{|c|}{ Unilateral } \\
\hline & & & & Right Ear & Left Ear \\
\hline \multirow{2}{*}{ Girls } & \multirow{2}{*}{4020} & \multirow{2}{*}{$764(19 \%)$} & \multirow{2}{*}{$237(31 \%)$} & \multicolumn{2}{|c|}{$527(69 \%)$} \\
\hline & & & & $261(49.5 \%)$ & $266(50.5 \%)$ \\
\hline \multirow{2}{*}{ Boys } & \multirow{2}{*}{4071} & \multirow{2}{*}{$854(21 \%)$} & \multirow{2}{*}{$276(32.3 \%)$} & \multicolumn{2}{|c|}{$578(67.7 \%)$} \\
\hline & & & & $298(51.6 \%)$ & $280(48.4 \%)$ \\
\hline \multirow{2}{*}{ Total } & \multirow{2}{*}{8091} & \multirow{2}{*}{$1618(20 \%)$} & \multirow{2}{*}{$513(31.7 \%)$} & \multicolumn{2}{|c|}{$1105(68.3 \%)$} \\
\hline & & & & $559(50.6 \%)$ & $546(49.4 \%)$ \\
\hline
\end{tabular}

classified into two groups: unilateral or bilateral hearing losses. Unilateral hearing loss was recognised when there was normal hearing in one ear and hearing loss in the other with threshold values equal or greater than $25 \mathrm{~dB}$ at one or more frequencies (13). Subsequently, according to previously established protocols $(12,17)$, data showing abnormal audiometric patterns was assigned to one of three categories:
Among children beginning education with an abnormal hearing screening result, HFHL was more common, affecting 35.8\% (763 ears), than LFHL, which accounted for $23.8 \%$ (508 ears). The remaining $40.4 \%$ (860 ears) were made up of hearing losses at other frequencies.

The audiometric results were supplemented with a questionnaire completed by 7312 parents (90.4\% of all parents of children who took part in the study). Their answers are shown in Table 2. It is in- 
Table 2. Results of the questionnaire

\begin{tabular}{|c|c|c|c|c|}
\hline \multirow{2}{*}{ Question } & \multirow{2}{*}{ Answer } & \multirow{2}{*}{$\begin{array}{l}\text { Number of } \\
\text { Responses }\end{array}$} & \multicolumn{2}{|c|}{$\begin{array}{l}\text { Hearing Screening } \\
\text { Result }\end{array}$} \\
\hline & & & Negative & Positive \\
\hline \multirow{2}{*}{$\begin{array}{l}\text { Do you think your child has any problems } \\
\text { with his/her hearing? }\end{array}$} & No & 6913 & 5596 & 1317 \\
\hline & Yes & 399 & 269 & 130 \\
\hline \multirow{3}{*}{$\begin{array}{l}\text { Does your child complain of tinnitus in their } \\
\text { ears/head when it is quiet? }\end{array}$} & Very often and often & 46 & 34 & 12 \\
\hline & Rarely & 678 & 536 & 142 \\
\hline & Never & 6588 & 5295 & 1293 \\
\hline \multirow{2}{*}{ Does your child often listen to loud music? } & No & 6611 & 5308 & 1303 \\
\hline & Yes & 701 & 557 & 144 \\
\hline \multirow{2}{*}{ Has your child been treated for otitis media? } & No & 5141 & 4158 & 983 \\
\hline & Yes & 2171 & 1707 & 464 \\
\hline \multirow{2}{*}{$\begin{array}{l}\text { Does your child complain about noise at } \\
\text { school? }\end{array}$} & No & 6539 & 5241 & 1298 \\
\hline & Yes & 773 & 624 & 149 \\
\hline
\end{tabular}

teresting to compare parents' answers with their children's hearing results.

The results of the questionnaire concerning parents' awareness of hearing disorders showed that when it came to the 1317 children who had positive screening results, $91.02 \%$ of their parents did not notice any problems with hearing. However, it should be added that in the majority of cases (68.9\%) this concerned unilateral hearing losses. Interestingly, 269 parents said that their child had a hearing problem, but pure tone audiometry did not confirm this. Tinnitus was also considered in the questionnaire. It was observed that $9.9 \%$ of children experienced tinnitus: $6.3 \%$ experienced it very often or often, and $93.7 \%$ rarely. Of the children who had a positive result at the hearing screening examination, $26.1 \%$ experienced tinnitus very often or often, compared to $21 \%$ who rarely experienced tinnitus.

The questionnaire indicated that $29.7 \%$ of the children had previously received treatment for otitis media. In addition, over one-fifth of the children with positive results from the hearing examination had had ear infection in the past.

Moreover, $10.6 \%$ of the examined children complained of excessive noise at school. One in five children complaining of noise at school had a positive result at the hearing screening examination.

The data confirm the need to increase the availability of medical services in rural areas, with hear- ing disorders showing up in a significant percentage of school-age children. Detecting hearing loss in a student starting school, and then treating it, is likely to improve the child's chances of a successful school education and of fulfilling their potential (11).

\section{DISCUSSION}

Hearing screening programs have an essential preventive role, being the basic tool of secondary prophylaxis. Screening allows for an early diagnosis of hearing disorders, thus enabling quick treatment and eliminating or minimizing the negative consequences associated with this type of dysfunction. In this study, data were collected from first-grade children from primary schools in rural areas of the Podkarpackie Voivodeship. A positive result was obtained in 1618 children (20\% of the examined children). All children with a positive result were referred for further diagnosis to an audiologist or an ENT specialist. This result is comparable with research carried out in Poland in the Warmian-Masurian Voivodeship, which showed that $19 \%$ of children from grades I-III of primary schools had a positive result of screening examination (3). In comparison, the prevalence of hearing loss in school-age children from rural areas throughout Poland has been estimated to be $16.4 \%$ (17). Data from pilot hearing screening projects, conducted by the Institute of Physiology and Pathology of Hearing in various African countries, have shown a prevalence of hearing loss of $18-34 \%$ (16), while in 
Piotr Henryk Skarzynski, Weronika Swierniak, Dorota Szuber et al.

Asian countries hearing loss was found in the range of $15.9-24.1 \%(12,13)$. Govender and Mars (18) assessed 146 ears of students at a school in South Africa and found that $16 \%$ (23 ears of 20 children) presented with hearing loss. The variability in prevalence may be explained by different sample numbers, different evaluation protocols, and by the various ages of the children (19). Our findings show that unilateral hearing loss (UHL) was more frequent (68.3\%) than bilateral hearing loss (BHL) 31.7\%, which is in line with results reported by a previous study in Poland (17). In a study conducted by Sekhar et al. (20), single-sided hearing loss was found to be as high as $88 \%$ (59 children from 67 with hearing impairments) in a group of 296 assessed children. Binaural hearing offers the listener several important advantages over monophonic hearing. It has been established that binaural hearing provides better speech perception, better sound localisation, increased loudness perception through binaural summation, and an overall improvement in hearing in both noisy and quiet environments (21).

Low-frequency hearing losses were identified in $23.8 \%$ of the ears with positive results. Our result is in line with results from Poland which indicate a similar rate of LFPTA HL (23\%) (3). In Nigeria, results of hearing screening indicate that $33.4 \%$ of children with positive screening results had a LFHL (167 out of 500 examined children) (22). In some cases, a lowfrequency hearing loss may be temporary ${ }^{23}$, and, depending on the specifics of the individual case, pharmacological or surgical intervention may be effective. The most common reasons for this kind of hearing loss are cerumen, perforation of the ear drum, tympanosclerosis, and otitis media with effusion ${ }^{24}$.

High-frequency hearing losses were identified in $35.8 \%$ of the ears with positive results. Data reported in another study conducted in Warmian-Masurian Voivodeship indicated an even higher rate of HFHL $-43.9 \%$ of ears had a positive result. In comparison, hearing screening in Tajikistan found that the percentage of children with HFHL was 25.5\% (12). Causes of high-frequency hearing loss in children can be noise, disease, infection, or genetic factors (25). Children with HFHL may appear to be inattentive or distractible due to difficulties understanding speech in noise. Recesses can be very noisy, which can lead to social problems if a child is unable to hear or misinterprets information in these situations (26). In HFHL, speech disorders and articulation problems can arise. It is important that children with HFHL should be permanently supported in school and in their home environment (27).

Results of the objective hearing screening were supplemented with information from a questionnaire completed by parents. We found that only about $9 \%$ of the parents suspected a problem with their child's hearing. This result was lower than the measured prevalence of hearing loss in the children. Moreover, the parents' opinions were not accurate. These results are in line with other researchers' findings $(28,29)$ and show that parents have difficulty in identifying hearing problems in their children and tend to underestimate it.

The screening procedures we used make it possible to detect not only children with hearing loss, but also those with other hearing disorders, such as tinnitus. Tinnitus is becoming a common problem in school-age children. In our study, prevalence of tinnitus was estimated to be $9.9 \%$. This result is in line with a study showing that the incidence of tinnitus in Polish children, aged between 7 and 12 years, ranges from a few percent to $12 \%$ or more depending on the child's age and place of residence (30). A similar result was reported from Tajikistan, where the figure was $9 \%$ of children (12).

\section{CONCLUSION}

Detecting hearing impairments in school-age children is essential. The later a hearing disorder is detected, the greater is the likelihood of poor future outcomes. In view of the significant number of children with positive screening results, we conclude that it is imperative to implement a universal school hearing screening program in Poland. Early diagnosis allows referral to specialists, who can then provide appropriate rehabilitation and thereby minimize or eliminate the negative impacts on a child's cognitive, social, emotional, and communication abilities.

\section{REFERENCES}

1. Niskar AS, Kieszak SM, Holmes A, Esteban E, Rubin C, Brody DJ. Prevalence of hearing loss among children 6 to 19 years of age: the Third National Health and Nutrition Examination Survey. JAMA. 1998; 279(14):1071-5. doi:10.1001/jama.279.14.1071. 
2. Feder KP, Michaud D, McNamee J, Fitzpatrick E, Ramage-Morin P, Beauregard Y. Prevalence of hearing loss among a representative sample of Canadian children and adolescents, 3 to 19 years of age. Ear Hear. 2017; 38(1):7. doi:10.1097/ AUD.0000000000000345.

3. Skarżyński PH, Łuszcz C, Świerniak W, Tarczyński K, Matusiak M, Włodarczyk AW, et al. Hearing screening of school children in the Warmian-Masurian Voivodeship. J Hear Sci. 2020; 9(2):36-44. doi:10.17430/1002937.

4. Skarżyński H, Piotrowska A. Screening for preschool and school-age hearing problems: European Consensus Statement. Int J Pediatr Otorhinolaryngol. 2012; 76(1):120-1. doi:10.1016/j. ijporl.2011.10.016.

5. World Health Organization. Addressing the Rising Prevalence of Hearing Loss. 2018 https://apps.who. int/iris/handle/10665/260336.

6. Bess FH. The minimally hearing-impaired child. Ear Hear. 1985;6(1):43-7. doi: 10.1097/00003446-198501000-00012.

7. Georgalas C, Xenellis J, Davilis D, Tzangaroulakis A, Ferekidis E. Screening for hearing loss and middle-ear effusion in school-age children, using transient evoked otoacoustic emissions: a feasibility study. J Laryngol Otol. 2008; 122(12):1299-1304. doi:10.1017/S0022215108002156.

8. Fortnum H, Ukoumunne OC, Hyde C, Taylor RS, Ozolins M, Errington S, et al. A programme of studies including assessment of diagnostic accuracy of school hearing screening tests and a cost-effectiveness model of school entry hearing screening programmes. Health Technol Assess Winch Engl. 2016; 20(36):1-178. doi:10.3310/hta20360

9. Skarzynski H, Kochanek K, Senderski A, Skarzynski PH, Ludwikowski M, Kopaczewski M, et al. Organization of the hearing screening examinations in Polish schools in rural areas and small towns. Cochlear Implants Int. 2010;11 Suppl 1:143-7. doi:10 $.1179 / 146701010 X 12671177647669$.

10. Skarżyński PH, Kochanek K, Skarżyński, H, Senderski A, Wysocki J, Szkielkowska A, et al Hearing screening program in school-age children in Western Poland. Int Adv Otol. 2011; 7:194-200.

11. Gos E, Ludwikowski M, Skarżyński PH, Skarżyński H. Elementy profilaktyki i edukacji zdrowotnej w badaniach przesiewowych słuchu dzieci w wieku szkolnym. Nowa Audiofonologia. 2017;6(3):19-25.

12. Skarzyński PH, Świerniak W, Piłka A, Skarżynska MB, Włodarczyk AW, Kholmatov D, et al. A hearing screening program for children in primary schools in Tajikistan: A telemedicine model. Med Sci Monit Int Med J Exp Clin Res. 2016; 22:242430. doi:10.12659/msm.895967.

13. Skarżyński PH, Świerniak W, Gos E, Pierzyńska I, Walkowiak A, Cywka KB, et al. Results of hearing screening of school-age children in Bishkek, Kyrgyzstan. Prim Health Care Res Dev. 2020; 21:e18. doi:10.1017/S1463423620000183.

14. Śliwa L, Hatzopoulos S, Kochanek K, Piłka A, Senderski A, Skarżyński PH. A comparison of audiometric and objective methods in hearing screening of school children. A preliminary study. Int J Pediatr Otorhinolaryngol. 2011; 75(4):483-8. doi:10.1016/j.ijporl.2010.12.024.

15. Tyler RS, Wood EJ. A comparison of manual methods for measuring hearing levels. Audiol Off Organ Int Soc Audiol. 1980; 19(4):316-29. doi:10.3109/00206098009072672.

16. Skarżyński PH, Piłka A, Ludwikowski M, Skarżyńska MB. Comparison of the frequency of positive hearing screening outcomes in schoolchildren from Poland and other countries of Europe, Central Asia, and Africa. J Hear Sci. 2014; 4(4):51-8.

17. Skarżyński H, Gos E, Świerniak W, Skarżyński $\mathrm{PH}$. Prevalence of hearing loss among polish school-age children from rural areas - Results of hearing screening program in the sample of 67416 children. Int J Pediatr Otorhinolaryngol. 2019;128:109676. doi:10.1016/j.ijporl.2019.109676.

18. Govender S, Latiff N, Asmal N, Ramsaroop S, Mbele T. Evaluating the outcomes of a hearing screening service for grade one learners in urban areas at Durban, South Africa. J Public Health Afr. 2015;6(1):529. doi:10.4081/jphia.2015.529.

19. Piotrowska A, Zapert A, Tarczyński K, Kochanek K. Analiza wybranych parametrów audiometrycznych przesiewowych badań słuchu wykonywanych w szkołach. Nowa Audiofonologia. 2014;3(4):9-13.

20. Sekhar DL, Rhoades JA, Longenecker AL, Beiler JS, King TS, Widome MD, et al. Improving detection of adolescent hearing loss. Arch Pediatr Adolesc Med. 2011; 165(12):1094-100. doi:10.1001/ archpediatrics.2011.188. 
Piotr Henryk Skarzynski, Weronika Swierniak, Dorota Szuber et al.

21. Vila P, Lieu JEC. Asymmetric and unilateral hearing loss in children. Cell Tissue Res. 2015; 361(1):271-8. doi:10.1007/s00441-015-2208-6.

22. Adejumo AMO and OR. An Investigation of Hearing Loss among School Age Children through $\mathrm{Au}-$ diological Assessment in Ibadan, Oyo State, Nigeria. İlköğretim Online Il 2011 Cilt 10 Sayı 1. Published online 2011. Accessed July 3, 2020. http://agris.fao.org/agris-search/search. do?recordID=TR2016025085

23. Czech D, Malicka M, Kott E, Zakrzewska A. Ocena występowania zaburzeń artykulacyjnych u dzieci z nawracającymi infekcjami górnych dróg oddechowych. Otorynolaryngologia. 2011; 10:116-20.

24. Minovi A, Dazert S. Diseases of the middle ear in childhood. GMS Curr Top Otorhinolaryngol Head Neck Surg. 2014; 13:Doc11. doi:10.3205/cto000114.

25. Wilcox SA, Saunders K, Osborn AH, Arnold A, Wunderlich J, Kelly T, Collins V, et al. High frequency hearing loss correlated with mutations in the GJB2 gene. Hum Genet. 2000; 106(4):399-405. doi:10.1007/s004390000273.

26. Skarżyński PH, Ludwikowski M. Hearing Screening around the World. Excursus Hear Loss. Published online May 30, 2018. doi:10.5772/ intechopen.73535
27. Stelmachowicz PG, Pittman AL, Hoover BM, Lewis DE, Moeller MP. The importance of high-frequency audibility in the speech and language development of children with hearing loss. Arch Otolaryngol Head Neck Surg. 2004;130(5):556-62. doi:10.1001/archotol.130.5.556.

28. Lo PSY, Tong MCF, Wong EMC, van Hasselt CA. Parental suspicion of hearing loss in children with otitis media with effusion. Eur J Pediatr. 2006; 165(12):851-7. doi:10.1007/s00431-006-0181-5.

29. Kaspar A, Newton O, Kei J, Driscoll C, Swanepoel DW, Goulios H. Parental knowledge and attitudes to childhood hearing loss and hearing services in the Solomon Islands. Int J Pediatr Otorhinolaryngol. 2017; 103:87-92. doi:10.1016/j.ijporl.2017.10.003.

30. Raj-Koziak D, Skarżyński H, Kochanek K, Fabijańska A. The prevalence of tinnitus in children in Poland. Otolaryngol Pol. 2013; 67(3):149-53. doi: 10.1016/j.otpol.2013.02.003. 